NGTT Deel 54, Nommers 1 \& 2, Maart en Junie 2013

\title{
Hendriks, H Jurgens ${ }^{1}$ \\ Stellenbosch University
}

\section{Aids, CURricula AND Gender in tWelVe African theOlogical SCHOOls}

\begin{abstract}
The article deals with the three related issues mentioned in the title in twelve theologi cal schools that formed a network called NetACT. A questionnaire on these matters was answered by al the institutions. The article discusses the answers to three basic questions: did they implement the HIV and AIDS curricula that their network developed; what was the influence and place of these programs in their curricula and what is the gender equity situation and attitudes like at their institution? The data reveals that by addressing the issue forcefully ever since 2000 the NetACT network has decidedly changed the culture of silence and stigmatisation prevalent in the surrounding society. The article thus gives one an insider view of how African seminaries struggle with HIV and AIDS issues. As to gender it is clear that in the network's schools female lecturers overwhelmingly feel accepted and treated as equals. They are taken seriously and listened to in classes by the students and in staff meetings by their male colleagues. However, the plight of women in African society is not an easy one. What this entails is spelled out in the answers.
\end{abstract}

\section{INTRODUCTION}

This article follows a previous article titled Networking theological education in Africa - the NetACT story, that told the story of the Network for African Congregational Theology (NetACT) and dealt with its founding, growth and important statistical data that helped to outline the contextual situation of the theological schools. The collected data was statistically quantified in order to show the existence or not of unequal gender representation in the participating theological schools and the churches that are their clients. ${ }^{2}$ Since the research was part of a project on AIDS, curriculum and gender, questions about these issues in the churches and schools were asked, but the absence of factual data led to speculation and uncertainty. We wanted to see what the gender ratios at our institutions are like because we argued that the lack of women in leadership positions in church and theological institutions is one of the major reasons why HIV and AIDS programmes as such will not stop the pandemic. This article reports on three research questions.

1. We wanted to know whether or not the seminaries implemented the HIV and AIDS programmes that their project team developed.

2. We wanted to know about the influence and place of these programmes in their curricula.

3. We wanted to get some understanding of the gender equity situation and attitudes to gender equality at our seminaries.

1 Jurgens Hendriks is Professor Emeritus in Practical Theology and Missiology at Stellenbosch University, South Africa. He is a founding member of NetACT and serves as the network's Executive Director. Email hjh@sun.ac.za

2 Hendriks, HJ. 2012. Dutch Reformed Theological Journal, 53:3\&4:120-129. 
NGTT: Oopbron - http://ngtt.journals.ac.za

The NetACT Board developed a hypothesis that motivated these research questions. When the network was founded in 2000 and its vision and goals were formulated in 2001, it announced as one of its goals:

To address the HIV and AIDS problem, especially by providing the theological, moral and spiritual undergirding to curb this pandemic.

NetACT developed HIV and AIDS programmes and wrote a book on the topic ${ }^{3}$ but then realised that even though the programmes or modules dealing with HIV and AIDS were taught by someone who was trained to do so, they were often "outsiders" in a course that does not integrate the content with the rest of the theological programme. It was pretty much an "addon" about something shrouded in silence and stigma. In other words there was little coherence with the rest of the curriculum of the institution.

In order to effectively and faithfully address the contextual reality of the HIV and AIDS pandemic, everybody teaching in an institution should deal with it purposefully in every subdiscipline of theology with the type of input unique to that sub-disciple. To achieve this, the students, staff and board of theological institutions should be familiar with the basic principles of constructing and teaching a contextualised curriculum. The basic elements of curriculum development should be known and applied. This was certainly not the case in the Network schools. Thus, in 2006 in Windhoek the Board decided to ask Rev. Kruger du Preez to do a doctoral dissertation in which his research examined the curriculum (development) situation at the schools. In 2009 we started with curriculum development workshops, which led to the realisation that this should be done with all staff and board members of an institution present. These workshops were very well received and helped the seminaries in many ways. ${ }^{4}$ They were motivated to contextualise the HIV and AIDS modules and address the pandemic holistically. It also helped the seminaries to work towards getting national and international accreditation.

It was during this process that we realised that our goal to address the HIV and AIDS pandemic would never be successful without addressing the cultural bias that existed in a patriarchal system $^{5}$, in other words, the gender issue. Thus the central hypothesis of the research questions that we are now discussing is that the reality of the HIV and AIDS pandemic will not be eradicated without addressing the gender issue in our culture and thus in our theological curricula.

The logic of this hypothesis and the importance of explaining it also had to be made clear to those churches and NGOs that had supported our work and research over the past ten years; we had to explain why we moved from simply writing HIV and AIDS programmes to engaging with issues of curriculum development and then gender equality work. The original goal is still being pursued, but we are addressing it on a much more fundamental level.

3 Mash, R. (et al). 2009. Our Church has AIDS. Preaching about HIV \& AIDS in Africa Today.

Stellenbosch: NetACT.

4 The reports of some of these workshops are available at http://academic.sun.ac.za/theology/netact/2011Malawi.html, http://academic.sun.ac.za/theology/netact/2011-Angola.html and http://academic.sun.ac.za/ theology/netact/2012-Nigeria.html accessed 27 June 2012.

5 On patriarchy and its influence on the different continents on the globe, see Castells (2004:192-302). He defines patriarchy as: is the founding structure of all contemporary societies. It is characterized by the institutionally enforced authority of all males over females and their children in the family unit (:192) ... $B y$ the crisis of the patriarchal family I refer to the weakening of a model of family based on the stable exercise of authority / domination over the family by the adult male head of the family. (:196). 


\section{Methodology}

A few remarks about methodology are necessary. The previous article ${ }^{6}$ quoted from the covering letter and the instructions on how the questionnaire should be completed. When the questions pertaining to HIV and AIDS and gender were asked, specific reference was made to the HIV and AIDS modules developed by the institutions through NetACT's mediation as well as to the curriculum development workshops. It was thus clear to the respondents that the gender questions were related to the HIV and AIDS as well as the curriculum issues.

The questions from the second part of the questionnaire are extremely sensitive within our African cultural setting. They dealt with the gender topic and how women were treated in church, seminary and community. The default response to these issues is silence. Instead of silence, the questions boldly expected to initiate a conversation about the elephant in the room, an elephant that cultural expectations demand should not be mentioned. Notwithstanding the cultural constraints, the answers conveyed an openness and trust that endorse the statement made in the previous article about the high levels of mutual trust between the institutions in this network.

In August 2011 the NetACT Board and the women delegates from the seminaries for the first time openly and directly addressed the gender issue. During the evaluation session several of the principals requested that we handle this issue with the utmost care. If we really want to serve the gender cause, we should be culturally sensitive. The attitude with which we approached the issue held the key to the success or failure with which it is addressed. In the evaluation of the workshop it was evident that the delegates picked up the smallest of signs of any arrogance about these issues. On the other side of the equation, it was equally clear that the men and the women who attended the workshop (in equal numbers) were more than willing to set out on this most challenging of cultural and spiritual journeys.

The key to this journey was a spiritual one and the firm conviction was that the answers to our quest should be sought in the Bible. Thus, the second part of the book that was the result of the August 2011 workshop ${ }^{7}$ dealt with this challenge.

Let us return to the methodology issue. In the light of the above-mentioned sensitivities, the questions about how women experience gender issues in their seminaries and churches were highly sensitive. They were working with and under the "protection" of their principal. The answers to the last two series of questions that tried to assess the degree of gender discrimination could have put them in an awkward position if, for instance, the principal got hold of them and could trace the answers to an individual staff member. Thus the following guidelines were set:

Questions 30 and 31 should be duplicated for each female staff member. Their answers should be treated as anonymous and confidential. The delegate female researcher should be solely responsible for this part and either email or post this section in such a way that anonymity and confidentiality are guaranteed.

To the credit of the principals it should be said that they respected this request and gave female staff members the freedom they needed to answer the questions anonymously and without fear. 
NGTT: Oopbron - http://ngtt.journals.ac.za

In the compilation of the data the researcher's first choice was to use the exact words of the respondents. However, in most cases the responses had to be edited and abbreviated to what can now be read in the tables below. Because the researcher is familiar with the institutions and the respondents as well as the cultural setting, it was possible to grasp what the respondents were trying to convey in a second and often third language.

\section{Discussion of the QUESTIONNAIRE RESULTS / TABLES}

\section{Table 6: Implementation of the NetACT HIV and AIDS curriculum}

The first remark to make regarding the table is that, in comparison to the situation in 2000 when the Network as founded and none of the institutions had a module on HIV and AIDS, all the institutions now had programmes in place. Nine used the material developed by their lecturers in collaboration with other experts that NetACT invited to help them write contextualised modules. The three institutions that are not using the exact modules which they helped to create obviously continued to create programmes that satisfied their needs.

\section{Some remarks}

- Janet Brown attended the now legendary NetACT meeting in 2002 at ABC in Lilongwe, Malawi where she initiated ABC's HIV programme. She was a fully qualified intensive care nurse. The plight of people in townships and squatter camps led her to start ministering to those people together with $A B C$ students. She did her doctoral degree on this topic. ${ }^{8}$ She later died of cancer, after which Rev. Maggie Madimbo, another ABC staff member, continued with the programme and work. She is at present completing her doctoral degree in the USA.

- $\quad$ NetACT developed its own publication on the process of HIV and AIDS curriculum development: Mash, Rachel, Cilliers, Johan, Griffiths, Keith, Chemorion, Edith \& Katani, Archwells (Eds). 2009. Our church has AIDS. Preaching about HIV \& AIDS in Africa today. Stellenbosch: NetACT. Copies can be ordered from the NetACT office (e-mail netact@ sun.ac.za).

- $\quad$ The MTh programme in Clinical Pastoral Care and Counselling (HIV and AIDS) is training eight students per year as specialised professional counsellors. Four African universities present this programme in collaboration with the Swedish government. For more information contact the NetACT office at netact@sun.ac.za or the secretary of the Department of Practical Theology (brobyn@sun.ac.za).

- The books mentioned in the answers are:

- Van Dyk, Alta. 2008. HIVAIDS Care \& Counselling: a multidisciplinary approach. Cape Town: Pearson Education. $4^{\text {th }}$ edition.

- Musa W Dube was mentioned. Some of her books are:

- Dube, Musa W. 2003. HIV/AIDS and the curriculum: methods of integrating HIV\&AIDS in theological programmes. Geneva: WCC.

8. Brown, Janet L. 2004. HIV/AIDS Alienation: Between Prejudice and Acceptance. Unpublished doctoral dissertation, Stellenbosch University. Online at http://scholar.sun.ac.za/handle/10019.1/5491 [Accessed: March, 16, 2012]. 
NGTT Deel 54, Nommers 1 \& 2, Maart en Junie 2013

- Dube, Musa W. \& Kanyoro, R.A. 2004. Grant me justice! HIV/AIDS \& gender readings of the Bible. Pietermaritzburg: Cluster.

- Dube, Musa W. \& Phiri, Isabel A. 2003. Africa praying: a handbook on HIV-AIDS sensitive sermon guidelines and liturgy. Geneva: WCC.

The realities with which the Network has to cope can be illustrated by two answers to the question: "If you have not implemented the (NetACT) HIV and AIDS curriculum, why not?"

- Hefsiba answered the question in the following way: The proposed curriculum by the workgroup of NetACT was never officially sent to us. There was no follow-up as to how to implement it. We did not receive any information on which books to use.

The writer of this article can explain what happened: Rev. Venancio Patrique was the Hefsiba lecturer whom NetACT trained. He helped to develop and translated all the material into Portuguese. However, after his training and as a result of his training he took up a much better paid appointment. This and the irritating lack of good e-mail and telephone communication with Hefsiba in those years explain how the problem arose.

Hefsiba is now using the following Portuguese books:

- Van Zyl, Daniel, Murray, Logy. 2003. Edificando a vossa habilidade para lidar com SIDA. Wellington: Instituto Biblico de Neemias; N7/3E. (In English: Building your ability to lead in Aids).

- Welbourn Alice, Williams, G and Williams, A. 2003. Caminhando de maos dados. Manual de Formacao sobre HIV/SIDA. Tecnicas de Commujnicacao e de Gestao de Relacoes Humanas. London: Strategies of Hope and ActionAid Mocambique. (In English: Walking together. Training manual on HIV/AIDS. Communication techniques and the issue of human relations.)

RTS Nigeria (which joined NetACT in 2010) reported: "We are yet to have a professional or expert in the field to handle the course. Also owing to stigmatisation of the pandemic (HIV), most people are reluctant to teach the course or even to receive training in order to teach it".

\section{Table 7: HIV and AIDS programmes and credits}

The table confirms that the HIV and AIDS modules taught are getting due recognition in the curricula of the schools. There are only two schools that seem not to be on standard at the moment. $A B C$ in Lilongwe Malawi has stopped teaching them because their designated lecturer is on sabbatical. She has in the meantime been informed of the situation and will certainly rectify it! RTS in Nigeria joined the network in 2010 and as such they have not been part of the campaign to address the pandemic in the way all the schools decided on. This difference highlights the influence of a network that addresses contextual issues.

\section{Table 8: Effectiveness of curriculum}

What a joy to read the answers in this table! They show the spectrum of motivations that makes the overwhelming Yes so interesting, as it highlights the influence and effect of the programme.

Table 9: HIV-positive students in the seminary? 
NGTT: Oopbron - http://ngtt.journals.ac.za

Six of the schools reported that they are not aware of any HIV-positive students living openly with HIV and AIDS and six schools do report known cases. The culture of silence - that is, not openly speaking out on these issues - can be illustrated by an observation. This researcher was teaching and staying at one of the schools where the woman who answered the questionnaire left this question open. One night I was awakened by someone crying out loud - obviously in grief. When I enquired the next day I was told that someone died that night and that she had AIDS. The principal of the school told me that several of their students died of AIDS-related deaths.

When the question: "Do you have lecturers who are openly living with HIV?" was asked, all institutions replied that there are no lecturers openly living with HIV and AIDS.

\section{Table 10: The impact of HIV and AIDS on seminaries}

The data of this table are really interesting and an eye-opener to the reality that theological schools face. The impact of HIV and AIDS is acknowledged by all. The disease has an impact on all the schools, and the illustrations of how and why this occurs reveal the devastating influence of the HIV and AIDS scourge. It is the openness of discussions like this that prove that by addressing the issue forcefully ever since 2000 the NetACT network has decidedly changed the culture of silence and stigmatisation prevalent in the surrounding society.

\section{Table 11: Most affected: women or men?}

The question was asked: "Who are most affected in your seminary?" Four respondents did not answer the question; one said that they could not really see any visible impact on campus (which was most probably the case in most schools). One mentions the reality of orphans. There must be very few households in Africa without orphans. Three respondents point out that, though one cannot really discern this on campus, women in general are most affected as a result of cultural, economic and societal factors.

\section{Table 12: About faithfulness and poverty}

It is important to remember that this question was put to the two respondents (the principal and the female delegate) to give their view on the public opinion about the question. Eleven of the twelve responses agreed that in the public opinion the unfaithfulness of women was a more serious matter than that of men. Ten of the twelve were certain that women suffer more than men.

The reasons why women are more affected by poverty were explained. Most often mentioned was the fact that they are not economically empowered (seven times). Indirectly all the answers give their precarious economic situation as the root cause. They referred to having to take care of the household, children, orphans and the vulnerable people of society (three times). Lack of education / illiteracy was mentioned three times. The impact of patriarchy is clear in all the answers. Women do not have access to land and cattle, and do not inherit. When a husband dies or when they are divorced, they often lose the basic necessities to life.

\section{Table 13: Women's experience of gender bias (or not)}

The methodology discussion explained how the 14 questions of this section were asked and how the respondents' anonymity was protected. Since there were ten respondents for 
NGTT Deel 54, Nommers 1 \& 2, Maart en Junie 2013

$\mathrm{SU}$, their combined response was mentioned in the first line of the table and those of the 20 respondents of eleven schools were mentioned in the second line. There is enough safety in numbers to refer to the SU group as an entity. This is not the case with other schools. It is therefore ethically correct not to mention how a specific school voted when there are only one or two respondents from that school. Where the totals of the first and second lines agree, they will be treated as a whole, i.e. a response out of $30(n=30)$. Where they differed significantly, this will be mentioned and discussed.

The first seven questions were intended to establish whether women lecturers experience gender bias and discrimination.

1. Do you feel accepted as a woman in your institution?

26 out of 30 agreed.

2. Do you feel treated as an equal in decision making?

26 out of 30 agreed.

3. Did you experience sexual harassment?

11 out of 30 agreed.

4. Equal promotion for female staff?

22 out of 30 agreed.

5. Taken seriously while teaching / in classes?

28 out of 30 agreed.

6. Taken serious in meetings by male staff?

27 out of 30 agreed.

7. Do female students have equal work opportunity?

13 out of 30 agreed.

It is clear that in the NetACT network's twelve schools female lecturers overwhelmingly feel accepted and treated as equals. They are taken seriously and listened to in classes by the students and in staff meetings by their male colleagues. This says a lot for these institutions and is something to be proud of.

There is, however, a serious issue: eleven female staff members have experienced what they regard as sexual harassment. Wisdom is needed in order to deal with this matter in a responsible way. Situations differ so much at the twelve schools that it would not be wise to prescribe a particular course of action. Leaving the matter in silence, however, would not be a wise move either.

The last question about whether female students have an equal chance of being called to congregations produced an interesting response: at Stellenbosch nine out of ten female staff members disagreed. Men get preference when congregations call ministers. This certainly was the case up to now in the DRC in SA. This researcher thinks that this tendency will change in the foreseeable future. The staff members of the 11 other schools voted the other way round. 12 out of 20 indicated that women have an equal chance of being called. The writer who compiled the answers can in this case say that it is clear that in some churches women will find it difficult to be ministers, while in other churches there is certainly less bias.

The second set of seven questions enquired about gender issues in the community.

1. Rape and abuse are serious problems.

2. Rape and abuse are seriously talked about

3. Domestic violence is treated seriously

4. There are safe places for women to talk
20 out of 30 agreed.

18 out of 30 agreed.

14 out of 30 agreed.

19 out of 30 agreed. 
NGTT: Oopbron - http://ngtt.journals.ac.za
5. There are safe places where women can get help
21 out of 30 agreed.
6. Bible views support violence against women
17 out of 30 agreed.
7. The church is a safe place for women to get help
17 out of 30 agreed.

The first remark is obvious: there are not clear cut answers to these questions that deal with the wider community in which the schools are located. In compiling the answers, it was clear that there are distinct differences between institutions. The highest level of agreement is that there are safe places where women can talk about their problems... yet only $70 \%$ agreed on this issue.

It is clear that in the communities in which the schools are situated women have a raw deal. If 17 out of 30 respondents indicate that popular opinion agrees that the Bible supports violence against women, no church, synod or seminary should feel proud of its teaching. The same number of women agree that the church is a safe place to get help. If thirteen disagree, this is a sad state of affairs. Seven out of ten women lecturers at SU don't find the church a safe place to get help. This is bad news.

It may also be said that there is progress. Rape and violence are in most cases regarded as serious problems and talked about. Domestic violence does not receive the same attention, but it is at least treated seriously, according to nearly half of the 30 women respondents. The fact that the highest score, 21 out of 30, indicates that there are safe places for women to get help, is encouraging.

\section{Conclusions}

The research questionnaire gave us clear answers to the three questions we asked.

In the first place the NetACT goal to seriously address the HIV and AIDS pandemic through its schools was certainly attained. At all the seminaries programmes teaching HIV and AIDS are in place. At the same time it is equally clear that this is a long journey that has only started.

Secondly, the network was successful in implementing HIV and AIDS curricula. They are having a positive effect, even though there is certainly room for improvement. This was clear from the answers received. HIV and AIDS certainly has a dire impact on students and institutions. It is clear that this is not directly seen in students or lecturers being HIV positive, but in the reality that everybody in church and society is directly affected by the pandemic.

However, it was equally clear that women are most affected by the pandemic and poverty. The patriarchal cultural system in particular discriminates against women and cause lots of pain and injustice.

The third question that the network wants to address, namely that of gender equity, proves to be a very valid concern. The result of the questions that addressed this issue proved without any doubt that gender inequality it is a sad reality in African cultures. But it did surprise us how much progress theological schools have made in this regard. There certainly still is a gender imbalance in seminaries when it comes to women as students and women as staff members. However, within the NetACT schools women by and large testify that they are well accepted and treated as equals.

In conclusion, the central hypothesis of the research questions is that the reality of HIV and 
NGTT Deel 54, Nommers $1 \& 2$, Maart en Junie 2013

AIDS pandemic will not be eradicated without addressing the gender issue in our culture and thus in our theological curricula. This hypothesis certainly holds true in the responses to the questionnaire and in the rationale of the NetACT network.

\section{BiBLIOGRAPHY}

Brown, Janet L. 2004. HIV/AIDS Alienation: Between Prejudice and Acceptance. Unpublished doctoral dissertation, Stellenbosch University. Online at http://scholar.sun.ac.za/handle/10019.1/5491 [Accessed: March, 16, 2012].

Dube, Musa W. \& Kanyoro, R.A. 2004. Grant me justice! HIV/AIDS \& gender readings of the Bible. Pietermaritzburg: Cluster.

Dube, Musa W. \& Phiri, Isabel A. 2003. Africa praying: a handbook on HIV-AIDS sensitive sermon guidelines and liturgy. Geneva: WCC.

Dube, Musa W. 2003. HIV/AIDS and the curriculum: methods of integrating HIV\&AIDS in theological programmes. Geneva: WCC.

Castells, M. 2004. The power of identity. The information age: economy, society and culture, volume II. $2^{\text {nd }}$ ed. Oxford: Blackwell.

Hendriks, H Jurgens; Mouton, Elna, Hansen, Len \& Le Roux, Elisabet. 2012. Men in the pulpit, women in the pew? Addressing gender inequality in Africa. Stellenbosch: SunMedia.

Hendriks, HJ. 2012. Networking theological education in Africa: the NetACT story in: Dutch Reformed Theological Journal, 53:3\&4:120-129,

Mash, Rachel, Cilliers, Johan, Griffiths, Keith, Chemorion, Edith and Archwells Katani (eds.). 2009. Our Church has AIDS. Preaching about HIV \& AIDS in Africa Today. Stellenbosch: NetACT.

Musa W Dube was mentioned. Some of her books are:

Van Dyk, Alta. 2008. HIVAIDS Care \& Counselling: a multidisciplinary approach. Cape Town: Pearson Education. $4^{\text {th }}$ edition.

Van Zyl, Daniel, Murray, Logy. 2003. Edificando a vossa habilidade para lidar com SIDA. Wellington: Instituto Biblico de Neemias; N7/3E. (In English: Building your ability to lead in Aids).

Welbourn Alice, Williams, G and Williams, A. 2003. Caminhando de maos dados. Manual de Formacao sobre HIV/SIDA. Tecnicas de Commujnicacao e de Gestao de Relacoes Humanas. London: Strategies of Hope and ActionAid Mocambique. (In English: Walking together. Training manual on HIV/AIDS. Communication techniques and the issue of human relations.)

\section{KEY WORDS}

HIV\&AIDS

Curriculum development

Gender equality

Stigmatization

NetACT

\section{TREFWOORDE}

MIV en vigs

Kurrikulum-ontwikkeling

Gender-gelykheid

Stigma

NetACT

\section{AdDENDA: THE TABLES}

The addenda below are the compiled data from the questionnaires. Both the questions and the detailed answers are important for research and researchers. 
NGTT: Oopbron - http://ngtt.journals.ac.za

Note to those who answered the questionnaire: In 2008 and 2009 some of your staff members attended the NetACT HIV curriculum development workshops. Ask knowledgeable staff member(s) to supply the information about your HIV \& AIDS modules.

\begin{tabular}{|l|l|l|}
\hline $\begin{array}{l}\text { Has the NetACT curriculum that was developed been implemented } \\
\text { at your seminary? If not, indicate what material you are using in this } \\
\text { regard. }\end{array}$ & YES & NO \\
\hline
\end{tabular}

ABC: Lilongwe Malawi

YES

The programme was first taught by the late Janet Brown, who did her DTh degree on HIV\&AIDS. Up to 2009 we were using the materials that we had developed up to that point at NETACT. Since Mrs Madimbo left to do doctoral studies (2010 onwards) the programme was not taught.

\section{Hefsiba: Vila Ulongue, Mozambique}

They are using some of the NetACT material used by the presenter of the NetACT programme as well as material from other sources (Logey \& Smith).

ISEU: Huambo, Angola

YES

ISTEL: Lubango, Angola

YES

JMTI: Nkhoma, Malawi

YES

JMTUC: Lusaka, Zambia

YES

They are also using internet sources, library sources, NetACT's book Our church has AIDS and a book by Musa Dube.

MThC: Masvingo, Zimbabwe

YES

NETS: Windhoek, Namibia

NO

They are using some of it, but added material from the Namibia Council of Churches.

\section{RITT: Eldoret, Kenya}

YES

\section{RTS: Mkar, Nigeria}

They joined NetACT in 2010 and report: The denominational HIV\&AIDS counsellor lectures on HIV\&AIDS to students every semester using his material. 
NGTT Deel 54, Nommers 1 \& 2, Maart en Junie 2013

Our faculty focuses on HIV and AIDS on different levels. We have a short course (official University certificate) in HIV and AIDS. This short course was developed in collaboration with the University's HIV and AIDS desk and the European Foundation. The content is based on a manual (consisting of different units) and the book by Alta van Dyk.

We also have an HIV and AIDS course/module as part of the MDiv programme in pastoral care. The focus in this programme is on the medical content and the counselling content. The book by Alta van Dyk and other material is used in this programme.

We also have a full Master's clinical program on HIV and AIDS. This is a one-year programme based on a clinical and academic programme as well as a research thesis. This programme was developed in collaboration with five other universities in Africa and the Swedish International Development Cooperation Agency.

\section{ZTC: Zomba, Malawi}

YES

\section{Table 7: HIV \& AIDS programmes and credits}

Question: Please indicate the following about the HIV\&AIDS curriculum that you are following: In which study years it is taught? In which programme (subject) it is taught? What is the credit value of the modules?

\section{ABC: Lilongwe Malawi}

An elective offered to $3^{\text {rd }}$ and $4^{\text {th }}$ year students in the Personnel Management two-credit programme.

\section{Hefsiba: Vila Ulongue, Mozambique}

Taught in first year. It is called SIDA (Portuguese for AIDS) 113 and 123. It has 8 credits each, which means there are two classes per week devoted to it for the whole year.

\section{ISEU: Huambo, Angola}

It is taught in the second year in the regular programme and fourth year in the part-time programme. It is considered a complementary subject and constitutes three credits or six hours per week.

\section{ISTEL: Lubango, Angola}

Taught in first year in the programme HIV\&AIDS. Three-credits programme or 45 hours a semester.

\section{JMTI: Nkhoma, Malawi}

Final year. Programme is called: HIV\&AIDS. Four hours per week.

\section{JMTUC: Lusaka, Zambia}

It is taught in the third year and called Pastoral Theology. 3 periods of 50 minutes each per week.

\section{MThC: Masvingo, Zimbabwe}

Taught in $2^{\text {nd }}$ year in the programme Practical Theology, which has a 4-credit value.

\section{NETS: Windhoek, Namibia}

$1^{\text {st }}, 2^{\text {nd }}, \& 3^{\text {rd }}$ years. It is called "African Social Issues in the first year ( 6 credits) and HIV \& AIDS in $2^{\text {nd }}$ and $3^{\text {rd }}$ years: 8 credits for the two years.

\section{RITT: Eldoret, Kenya}


NGTT: Oopbron - http://ngtt.journals.ac.za

It is taught in the second year. The programme is called "Interpreting the Bible in the light of HIV\&AIDS." The credit value of the modules is 2 hours per week.

\section{RTS: Mkar, Nigeria}

They joined NetACT in 2010. It is taught by the denominational AIDS counsellor once a semester to all students in all classes. These presentations carry no credit value.

\section{SU: Faculty of Theology, Stellenbosch South Africa}

A short 12-credit course was developed so that anybody with a senior certificate can enrol in this course. Thus it is open to the broader community. The MDiv programme (fifth year of the ministerial training) has a five-credit module on HIV and AIDS. The MTh Clinical Pastoral Care in HIV and AIDS is a full year, 180 credits. HIV and AIDS programmes are part of the Practical Theology curriculum.

\section{ZTC: Zomba, Malawi}

Taught in 3rd and 4th years in the programme: Practical Theology and Moral Issues. It constitutes $25 \%$ of the module.

\section{Table 8: Effectiveness of curriculum}

Question: Has the curriculum that you use been effective? Please motivate your answer.

\section{ABC: Lilongwe Malawi}

It certainly was effective. Students went for voluntary HIV testing - which was well received.

\section{Hefsiba: Vila Ulongue, Mozambique}

Yes, very much so. The students are well informed about the facts, but also of the ethical issues. The lecturer is following a very open approach in his teaching and there is a lot of discussion.

\section{ISEU: Huambo, Angola}

Yes. Our students are very effective activists and they are doing good work in their communities in Huambo and surrounding towns.

\section{ISTEL: Lubango, Angola}

It has been very effective even though it is only taught in the first semester of the BTh programme.

\section{JMTI: Nkhoma, Malawi}

Yes. Many pastors are now aware of HIV and AIDS and are not just negatively condemning it, but deal with it more positively.

\section{JMTUC: Lusaka, Zambia}

Yes. Students have acquired basic theological understanding of HIV and AIDS and are able to apply the knowledge in specific ministry situations.

\section{MThC: Masvingo, Zimbabwe}

To a certain extent. Most people are not ready to open up on issues of HIV and AIDS status.

\section{NETS: Windhoek, Namibia}

Yes, the curriculum is very effective, because it is practical and gives the students skills to minister to HIV\&AIDS. Some of our students are ministering to PLWHA.

\section{RITT: Eldoret, Kenya}


Yes; students are sensitive about PLWHA as well as to those who are affected by it. This is noticeable in their preaching.

\section{RTS: Nigeria}

They joined NetACT in 2010. They report: So far this has been effective. The students did well in the inter-seminary joint lecture session. The resource persons rated our students as being the most alert on issues of handling HIV and AIDS in ministry.

\section{SU: South Africa}

Yes, to a large extent. We had good feedback from the participants in the short course and the students in the MDiv programme. The MTh in Clinical Pastoral Care \& Counselling (HIV and AIDS) is regularly externally audited and updated with the latest research information.

\section{ZTC: Zomba, Malawi}

Yes. It helps students with: managing skills, counselling skills, pastoral skills and awareness raising in how to deal with the different age groups.

\section{Table 9: HIV-positive students in the seminary?}

Question: What is the effect of HIV and AIDS on the seminary and how many students do you have who are openly living with HIV?

\section{ABC: Lilongwe Malawi}

It is difficult to know the effect as it is not discussed publically. The school did lose students and other members due to HIV and AIDS.

\section{Hefsiba: Vila Ulongue, Mozambique}

If there is an effect, we don't know about it, because people are not open about it. We are not aware of HIV positive students.

\section{ISEU: Huambo, Angola}

Before the HIV module was implemented in the curriculum, silence reigned and HIV\&AIDS were simply seen as sin. Attitudes changed with the introduction of the modules. It clearly affects the church. We had two HIV positive students in 2010.

\section{ISTEL: Lubango, Angola}

At present there are no known cases of HIV positive students. However, before the HIV programme one of their students died because of HIV and AIDS.

\section{JMTI: Nkhoma, Malawi}

People are normally affected when one of their family members are sick or has died; then one has to excuse him or her from classes to attend the funeral. Since students have medical check-ups before being interviewed and allowed, the Executive Committee knows that there are two positive students.

\section{JMTUC: Lusaka, Zambia}

No answer. / Not aware of students who are HIV positive.

\section{MThC: Masvingo, Zimbabwe}

Everyone is affected in one way or another especially through close relatives who are infected. They are not aware of students who at present are HIV positive.

\section{NETS: Windhoek, Namibia}


NGTT: Oopbron - http://ngtt.journals.ac.za

No answer. / Not aware of students who are HIV positive.

\section{RITT: Eldoret, Kenya}

Not sure. Nobody comes out openly.

\section{RTS: Nigeria}

They joined NetACT in 2010 and report: Three of our students are infected with HIV and AIDS and are facing the challenges of fear of stigmatisation.

\section{SU: South Africa}

I do think the effect is due to the lack of students and staff who have been tested. Indirectly one can only imagine the emotional, economic and spiritual effect of family and friends living with HIV and AIDS must be high due to the reality of the infections in Africa. Some lecturers do know of HIV positive students.

\section{ZTC: Zomba, Malawi}

Today we live in a community where all have been affected in one way or another. The effects of this are some orphaned children being raised by relatives in the college community. The HIV and AIDS modules have inspired them to form an HIV and AIDS response group. / Not aware of students who are HIV positive.

\section{Table 10: The impact of HIV and AIDS on seminaries}

Questions: Do you have students and lecturers who are affected by HIV? How has HIV impacted your seminary?

\section{ABC: Lilongwe Malawi}

Students are affected, lecturers not. HIV and AIDS do affect the seminary, but are only talked about when someone dies.

\section{Hefsiba: Mozambique}

If there is an effect, we don't know that it is because of HIV and AIDS. People are not open about it. The impact of AIDS is not noticeable, but people are now aware of the dangers.

\section{ISEU: Huambo, Angola}

Students and lecturers are affected by HIV. The seminary is now more open to address the issue of HIV and AIDS as we are all affected by the problem. There is a theological approach concerning the issue and through Bible studies people are becoming more aware of the disease and they feel responsible to fight against this epidemic.

\section{ISTEL: Lubango, Angola}

At present no students or lecturers are known to be HIV positive, although everyone is affected by it.

\section{JMTI: Nkhoma, Malawi}

In Malawi there is no family that can say that it is not affected by HIV - thus everyone at JMTI is affected. HIV did impact on the seminary, for those infected are often ill and spend lots of money on medical bills; they miss classes and their performance is affected.

\section{JMTUC: Lusaka, Zambia}


Students and lecturers are affected by HIV. The college has lost some students due to HIV and AIDS-related illnesses.

\section{MThC: Masvingo, Zimbabwe}

All students and lecturers are affected by HIV. Lecturers are affected when students and lecturers attend funerals. There is financial strain on students and lecturers in assisting HIV and AIDS-infected relatives.

\section{NETS: Windhoek, Namibia}

Students and lecturers are affected by HIV. Impact: it has caused us to come up with additional courses that are relevant to the community around us. This meant major changes to the curriculum.

\section{RITT: Eldoret, Kenya}

Students and lecturers are affected by HIV. It impacts on the seminary in that most people are willing to know their HIV status and support vulnerable people in the society.

\section{RTS: Nigeria}

They joined NetACT in 2010 and report: We lost two students in the last two years to HIV. Some students have difficulty paying tuition fees as their relations who could support them are infected or affected.

\section{SU: South Africa}

They have students but not lecturers affected by HIV and AIDS. The effect is limited in terms of direct infections but it could be much more significant in terms of family and friends.

\section{ZTC: Zomba, Malawi}

All students and lecturers are affected by HIV. The impact is not much, because previously ministry students have gone through a screening process before joining ZTC. This has now been discouraged in order not to violate human rights. The situation might therefore change.

\section{Table 11: Most affected: women or men?}

Question: Who are most affected by HIV and AIDS in your seminary: Women or men? Why?

\section{ABC: Lilongwe Malawi}

Men are more affected because most of the students are men.

\section{Hefsiba: Vila Ulongue, Mozambique}

No visible impact.

\section{ISEU: Huambo, Angola}

It is difficult to evaluate who is more infected or affected by the disease, because at the moment none of the lecturers or students are assumed or confirmed HIV positive. But in practical terms women are more affected. Why? Because they have no power, even within some churches, they become more vulnerable.

\section{ISTEL: Lubango, Angola}

No answer.

\section{JMTI: Nkhoma, Malawi}

No answer. 
NGTT: Oopbron - http://ngtt.journals.ac.za

\section{JMTUC: Lusaka, Zambia}

Both are affected. Taking care of the orphans affects all.

\section{MThC: Masvingo, Zimbabwe}

Since there are more male students it is difficult to see who is more affected.

\section{NETS: Windhoek, Namibia}

No answer.

\section{RITT: Eldoret, Kenya}

Women. Why? They are victims of cultural practices that fuel the spread of HIV and AIDS. They are biologically vulnerable, often without power and as such often very poor.

\section{RTS: Nigeria}

Men. Men tend to be more unfaithful in marriage. They hide their status and claim not to have safe sex to prove they are not infected.

\section{SU: South Africa}

I do think both. Why? The male student living with HIV struggles with many issues that are known to me. But broader in terms of friends and family it must be women, because they are the most vulnerable in terms of our cultural and economic realities.

\section{ZTC: Zomba, Malawi}

No answer

\section{Table 12: About faithfulness and poverty}

Questions: We requested the two delegates to the Gender Equality workshop to give their opinion of what the view of the general public is on the following issue: Is it more serious if a wife is unfaithful to her husband or is it the other way round? Who is more affected by poverty: women or men? Explain.

\section{ABC: Lilongwe Malawi}

It is more serious if a wife is unfaithful. Women are more affected by HIV and since most people in Malawi live below the poverty line women are affected most. Also: more women are not educated and illiteracy makes poverty worse.

\section{Hefsiba: Mozambique}

It is more serious if a wife is unfaithful. Both genders are suffering, but perhaps women are suffering more, because often they are tending to the house, children and land. Men use the money they earn for themselves. If the man dies, the family of the husband will come and take everything.

\section{ISEU: Huambo, Angola}

It is more serious if a wife is unfaithful. In my opinion and according to the practical reality, women are more affected by poverty because they have less access to financial resources. They have no input in decision making which makes them more vulnerable to HIV and AIDS.

\section{ISTEL: Lubango, Angola}

It is more serious if a wife is unfaithful. Reasons: less access to finances and no say in decision making. 
NGTT Deel 54, Nommers 1 \& 2, Maart en Junie 2013

It is more serious if a wife is unfaithful. Pastors divorced unfaithful wives, but it does not happen when the husband is unfaithful. Culture and poverty make women stay and take care of the children.

JMTUC: Lusaka, Zambia

It is more serious if a wife is unfaithful. Both are affected since there is a high rate of unemployment.

\section{MThC: Masvingo, Zimbabwe}

It is more serious if a wife is unfaithful. Women are less economically empowered. They do not own cattle or land which are the traditional symbols of wealth.

\section{NETS: Windhoek, Namibia}

They are uncertain in which case unfaithfulness is more serious. Women are more affected by poverty in their communities because of their day-to-day responsibilities of taking care of the family.

\section{RITT: Eldoret, Kenya}

It is more serious if a wife is unfaithful. Women are less educated and they have no right of inheriting.

\section{RTS: Nigeria}

It is more serious if a wife is unfaithful. Most women depend on their husbands and do not have any personal means of livelihood. Men don't always provide women with what is needed.

\section{SU: South Africa}

It is more serious if a wife is unfaithful. Women are more affected by poverty because: 1) They are paid less for the same work (the situation is improving though); 2) Race plays a role, black women are paid least; 3 ) Women are taking responsibility for children, orphans, and all vulnerable people in society; 4) Because of these responsibilities they are often divorced and exposed to hardship and hopelessness.

\section{ZTC: Malawi}

It is more serious if a wife is unfaithful. Women are more affected because of illiteracy and the lack of economic empowerment.

\section{Table 13: Women's experience of gender bias (or not)}

The following questions were put to women staff members.

The first line represents the response of ten women from SU. The second line is the combined response of nine schools totalling 20 respondents. JMTI and RTS have no women on staff and did not respond to these questions. The = signifies the total of the 30 who answered $(n=30)$. 


\begin{tabular}{|c|c|c|c|c|c|}
\hline & & 츠ํ ฏ & ฐัँ & 迹 & 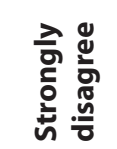 \\
\hline $30 a$ & $\begin{array}{l}\text { As a woman, I feel completely } \\
\text { accepted in our institution. }\end{array}$ & $\begin{array}{l}3 \\
12=15\end{array}$ & $\begin{array}{l}5 \\
6=11\end{array}$ & $\begin{array}{l}2 \\
2=4\end{array}$ & $=0$ \\
\hline $30 b$ & $\begin{array}{l}\text { I feel treated as an equal in } \\
\text { decision making. }\end{array}$ & $\begin{array}{l}3 \\
9=12\end{array}$ & $\begin{array}{l}6 \\
8=14\end{array}$ & $3=3$ & $\begin{array}{l}1 \\
0=1\end{array}$ \\
\hline $30 c$ & $\begin{array}{l}\text { I have experienced instances } \\
\text { of sexual harassment in the } \\
\text { seminary / faculty / college. }\end{array}$ & $\begin{array}{l}1 \\
6=7\end{array}$ & $\begin{array}{l}3 \\
1=4\end{array}$ & $\begin{array}{l}5 \\
8=13\end{array}$ & $\begin{array}{l}1 \\
5=6\end{array}$ \\
\hline $30 d$ & $\begin{array}{l}\text { Opportunities for promotion } \\
\text { and advancement are equal } \\
\text { for female staff members. }\end{array}$ & $\begin{array}{l}3 \\
7=10\end{array}$ & $\begin{array}{l}6 \\
6=12\end{array}$ & $5=5$ & $\begin{array}{l}1 \\
2=3\end{array}$ \\
\hline $30 e$ & $\begin{array}{l}\text { When I lecture, I feel like I am } \\
\text { listened to/taken seriously by } \\
\text { students ( } 1 \text { no answer). }\end{array}$ & $\begin{array}{l}3 \\
12=15\end{array}$ & $\begin{array}{l}6 \\
7=13\end{array}$ & $\begin{array}{l}1 \\
0=1\end{array}$ & $\begin{array}{l}0 \\
0=0\end{array}$ \\
\hline $30 f$ & $\begin{array}{l}\text { When at staff meetings I feel } \\
\text { I am listened to and taken } \\
\text { seriously by faculty members. }\end{array}$ & $\begin{array}{l}3 \\
11=14\end{array}$ & $\begin{array}{l}6 \\
6=12\end{array}$ & $\begin{array}{l}1 \\
3=4\end{array}$ & \\
\hline $30 \mathrm{~g}$ & $\begin{array}{l}\text { Your view please: Compared } \\
\text { with male students, women } \\
\text { students have an equal } \\
\text { opportunity of being called } \\
\text { to a congregation (1 no } \\
\text { answer). }\end{array}$ & $\begin{array}{l}0 \\
7=7\end{array}$ & $\begin{array}{l}1 \\
5=6\end{array}$ & $\begin{array}{l}6 \\
4=10\end{array}$ & $\begin{array}{l}3 \\
3=6\end{array}$ \\
\hline & Evaluate the following staten & ents & & & \\
\hline $31 a$ & $\begin{array}{l}\text { In my community, rape and } \\
\text { abuse are serious problems. }\end{array}$ & $\begin{array}{l}3 \\
4=7\end{array}$ & $\begin{array}{l}5 \\
8=12\end{array}$ & $6=8$ & $\begin{array}{l}0 \\
2=2\end{array}$ \\
\hline $31 b$ & $\begin{array}{l}\text { In my community, rape and } \\
\text { abuse are seriously talked } \\
\text { about. }\end{array}$ & $\begin{array}{l}0 \\
2=2\end{array}$ & $12=16$ & $3=7$ & $3=5$ \\
\hline $31 c$ & $\begin{array}{l}\text { Domestic violence is treated } \\
\text { seriously. }\end{array}$ & $\begin{array}{l}0 \\
6=6\end{array}$ & $\begin{array}{l}4 \\
4=8\end{array}$ & $\begin{array}{l}5 \\
8=13\end{array}$ & $2=3$ \\
\hline
\end{tabular}


NGTT Deel 54, Nommers 1 \& 2, Maart en Junie 2013

\begin{tabular}{|c|c|c|c|c|c|}
\hline $31 d$ & $\begin{array}{l}\text { There are safe spaces where } \\
\text { women can voice their pain. }\end{array}$ & $\begin{array}{l}0 \\
5=5\end{array}$ & $\begin{array}{l}7 \\
7=14\end{array}$ & $\begin{array}{l}2 \\
5=7\end{array}$ & $\begin{array}{l}1 \\
3=4\end{array}$ \\
\hline $31 \mathrm{e}$ & $\begin{array}{l}\text { There are safe spaces where } \\
\text { women can get help if } \\
\text { needed. }\end{array}$ & $6=6$ & $8=15$ & $5=8$ & $1=1$ \\
\hline $31 \mathrm{f}$ & $\begin{array}{l}\text { People's view of the Bible } \\
\text { supports violence against } \\
\text { women. }\end{array}$ & $\begin{array}{l}1 \\
1=2\end{array}$ & $\begin{array}{l}6 \\
9=15\end{array}$ & $\begin{array}{l}3 \\
7=10\end{array}$ & $\begin{array}{l}0 \\
3=3\end{array}$ \\
\hline $31 \mathrm{~g}$ & $\begin{array}{l}\text { The church is a safe place for } \\
\text { women to look for help for } \\
\text { domestic violence, rape and } \\
\text { abuse. }\end{array}$ & $\begin{array}{l}0 \\
5=5\end{array}$ & $\begin{array}{l}3 \\
9=12\end{array}$ & $\begin{array}{l}5 \\
3=8\end{array}$ & $\begin{array}{l}2 \\
3=5\end{array}$ \\
\hline
\end{tabular}

